\title{
In Vitro Antibacterial Activity of four Saudi Medicinal Plants
}

\author{
Alothyqi N ${ }^{1}$, Almalki M1', Albqa'ai $\mathbf{M}^{2,3}$, Alsamiri $\mathrm{H}^{1}$, Alrashdi SM${ }^{3}$, Ibraheem $\mathrm{F}^{2,3,4}$ and Osman $\mathrm{GHE}^{1,5^{*}}$ \\ ${ }^{1}$ Department of Biology, Umm Al-Qura University, 1109- Makkah Al-Mukarramah, Kingdom of Saudi Arabia \\ ${ }^{2}$ Al-Qunfudah Center for Scientific Research (QCSR), Al-Qunfudah- 21912, Kingdom of Saudi Arabia \\ ${ }^{3}$ Department of Chemistry, University College in Al-Qunfudah, Umm Al-Qura University, 1109-Makkah A-Mukarramah, Kingdom of Saudi \\ ${ }^{4}$ Botany Department, Faculty of Science, Mansoura University, Mansoura, 35516- Egypt \\ ${ }^{5}$ Agricultural Genetic Engineering Research Institute (AGERI), Giza, 12619- Egypt
}

\begin{abstract}
In the current study, we tested, evaluated and compared the antibacterial activity of twenty four extracts prepared from four traditional Saudi medicinal plants (Jatropha pelargoniifolia, Euphorbia inaequilatera, Cadaba glandulosa and Cadaba rotundifolia). The plant materials were extracted in six organic solvents with different polarity by two different extraction methods. The activity of these plant extracts were tested against three Gram-positive bacteria (Staphylococcus aureus, bacillus megaterium and Bacillus cereus) and four Gram-Negative bacteria (Klebsiella pneumoniae, Pseudomonas aeruginosa, Escherichia coli and Salmonella enteretidis. Minimum inhibitory concentrations (MICs) of the extracts were determined using the agar dilution method. Our results indicated that most of the tested extracts exhibited a significant broad-spectrum antibacterial activity against both Gram-Positive and Gram-Negative bacteria. The Euphorbia inaequilatera extracts were active against all tested bacterial strains whereas the other plant extracts showed selective activity at the level of both organic solvent and bacterial strain The use of different extraction solvents resulted in a substantial differences in the potency of the antibacterial activity of the extracts with acetone being the most effective solvent in the extraction of bioactive compounds from the tested plant species. In addition, a number of the tested plant extracts successfully recovered more than $70 \%$ of the Ciprofloxacin antibacterial activity. Cadaba glandulosa extracts showed the most potent antimicrobial activity against B. megaterum (MIC of 16 and $32 \mathrm{mg} / \mathrm{l}$ ). Different organic solvents as well as different extraction methods can be effectively employed to mine plants' phytochemical profiles and consequently illustrate their antibacterial activity against antibiotic resistant bacterial strains.
\end{abstract}

Keywords: Antimicrobial activity; Medicinal plants; Agar diffusion assay; Minimum inhibitory concentration

\section{Introduction}

Medicinal plants play a vital roles in the healthcare provision of numerous countries and they have been used as a drug treatment of major human diseases $[1,2]$.These plants have been classified by World Health Organization (WHO) as the best source of drugs [3]. In fact, important drugs like morphine, cocaine, codeine, digitoxin, and quinine are all of plant origin [4]. Interestingly, different drugs are obtained from different plant organs such as root, stem, flowers, and fruits $[5,6]$. Most of the bioactive medicinal metabolites are synthesized via plant secondary metabolic pathways during the vegetative stage of plant's life cycle and these compounds are responsible for the therapeutic properties of the medicinal plants [7]. Chemical or synthetic drugs and antibiotics have been used for treatment of human diseases and infections. In general, these compounds effectively inhibit and/or stop microbial growth via disruption of the synthesis of microbial nucleic acids, proteins and cell walls $[8,9]$. However, they are currently facing many health concerns. Recently, constant increase in microbial resistance to different trade drugs or antibiotic forms has been reported $[10,11]$. In addition, numerous studies have reported critical side effects of synthetic antibiotics on the human immune system [11,12]. Therefore, there is an emerging need for new innovative strategies to develop new and safe antibiotics. In this regard, traditional medicinal plants provide unique and promising alternative for achieving this goal because of the limited side effects and accessibility of plant derived drugs. In addition, these plant-derived drugs have the potential for restoring the activity lost because of bacterial resistant mechanisms. Unlike traditional antibiotics, the wide diversity of phytochemicals in plant extract put severe challenges on microorganisms to develop resistant mechanisms against them. As a result, investigation and screening of these plants for biologically active compounds with considerable antimicrobial activity has been a continuous process $[13,14]$ Medicinal plants are represented in almost all taxonomic plant families worldwide. Examples of families and specific examples include compositae (Chamomile, Matricaria chamomilla, Artichoke, Cynara cardunculus).Labiatae (Lavander, Lavandula officinalis, rosemary, Rosmarinus officinalis), Umbelliferae (carrot, Daucus carota, sea holly, Eryngium maritime, anise, Pimpinell aanisum), Leguminosae (false acacia, Robinia pseudoacacia, alfalfa, Medicago sativa, and fenugreek, Trigonella foenumgraecum), Rosaceae (Almond. Prunusdulcis), Rutaceae (orange, Citrus aurantium, lemon, Citrus limon) and Solanaceae (white henbane, Hyoscyamus albus, the Mediterranean withania, Withania somnifera). These plants have been used as a source of active compounds with differential abilities to inhibit the growth of microorganisms and drug resistant microbes $[15,16]$. The existence of a large number of medicinal plants in the flora of Saudi Arabia has also been reported [17]. These plants are distributed over about 36 various plant families. The two families, Euphorbiaceae and Capparidaceae are among these families which have a considerable number of traditional medicinal plant species. In Saudi Arabia, Euphorbiaceae family is represented by about 15 genera and 66 species that vary from herbs to shrubs and trees and from

*Corresponding author: Osman G, Department of Biology, Umm Al-Qura University, Makkah Al-Mukarramah, Kingdom of Saudi Arabia, Tel: +9662 5270000; E-mail: geosman@uqu.edu.sa

Received January 16, 2016; Accepted February 02, 2016; Published February 09, 2016

Citation: Alothyqi N, Almalki M, Albqa'ai M, Alsamiri H, Alrashdi SM, et al. (2016) In Vitro Antibacterial Activity of four Saudi Medicinal Plants. J Microb Biochem Technol 8: 083-089. doi: 10.4172/1948-5948.1000267

Copyright: (c) 2016 Alothyqi N, et al. This is an open-access article distributed under the terms of the Creative Commons Attribution License, which permits unrestricted use, distribution, and reproduction in any medium, provided the original author and source are credited. 
succulent to non-succulent plants. It has more than twenty species with diverse medicinal properties with about two endemic species [17]. The diverse medicinal properties of Euphorbiaceae members may be associated with their wide distribution in different habitats which seems to occur as a result of their high adaptive mechanisms such as Crassulacean Acid Metabolic (CAM) pathway and succulence [18]. Interestingly, a patent describing the extraction of bioactive flavonoid metabolites (4'-methoxy-luteolin-7-O-rhamnoglucoside and aromadendrin) from Euphorbia cuneata in Saudi Arabia has been issued by the United States Patent and trademark office (http:// patft.uspto.gov, Patent \# 20140288286,) [19]. Capparidaceae family is also widely spread in Saudi Arabia. It's members grow in the Red Sea coastal region, particularly in, Nagran, Abha, Bisha, south Jeddah to Medina area, and the area between Dahna and Arabian Gulf [20] It has about 28 genera and about 700 species of annual or perennial herbs, sub-shrubs, shrubs or trees [21] In addition, more than 12 medicinal species have been investigated and about four species being endemic to Arabian Peninsula. Interestingly, various members belonging to the family Euphorbiaceae have been widely used as traditional medicine in many parts of Eastern Africa and south Asia [22]. Also, different members of the family Capparidaceae are commonly used for treating various human diseases in many parts of India, Africa and Asia [23,24]. Successful identification of the right medicinal plant is crucial for the success of the entire process. Therefore, screening the planta kingdom for identification of wild plants with potential medicinal significance and selection of the appropriate extraction methods are the first critical steps in the discovery of plant-derived drug. As a result, the objectives of the current study were: (1) to test and evaluate the potential antimicrobial activity of extracts prepared from four Saudi's medicinal plants belonging to Euphorbiaceae and Capparidaceae and (2) compare the efficiency of various organic solvents and different extraction methods on the antibacterial activity of the selected plant extracts.

\section{Methods}

\section{Plant materials}

Four plant species were used in the current investigation. The selected plants were Jatropha pelargoniifolia, Euphorbia inaequilatera, Cadaba glandulosa and Cadaba rotundifolia (Table 1). The first two plants belong to the family Euphorbiaceae whereas the other two belong to the family Capparidaceae. These plants were collected on November 2014 either from Jeddah, AlQuonfodha, or from MakkahAlQuionfodha road as indicated in (Table 1). The collected plants were identified and classified by Prof. Dr. Kadry Abdel Khalik, a plant taxonomist at Biology Department - Umm Al-Qura University, Makkah, Saudi Arabia according to [25].

\section{Bacterial stocks}

Seven bacterial strains belong to both Gram-Positive and GramNegative bacteria were used in testing and evaluation of possible antibacterial activity of plant extracts. Gram-Positive bacteria were Staphylococcus aureus (NCTC 12989), Bacillus megaterium (DSM319), and Bacillus cereus (ATCC 15816), whereas Gram-Negative bacteria included klebsiella pneumoniae (ATCC-BAA 1705), Pseudomonas aeruginosa (ATCC 10145), Escherichia coli (MTCC 40), and Salmonella enteretidis (ATCC13076). The bacterial strains were obtained from the Department of Biology, Faculty of Applied Science, Umm Al-Qura University, Makkah, Saudi Arabia. Bacterial isolates were maintained on Mueller-Hinton Agar medium. Twenty four hour old pure cultures of bacteria were prepared for use each time according to [26-28].

\section{Preparation of plant extracts}

Plants were collected from different regions as indicated in (Table 1). The collected plants were then thoroughly washed with running water then blotted using filter paper. Plant organs of interest were collected and air dried at room temperature. Dried tissues were ground into fine powder using electric grinder and stored in dark colored bottles until use. Powdered plant tissues were extracted separately in water as well as in five individual organic solvents. Two methods of extraction were employed, namely, method A and method B. In method A, amounts of fifty grams of powdered plant tissues were extracted separately in $100 \mathrm{ml}$ of water and $85 \%$ four different organic solvents including methanol, ethanol, acetone, and petroleum ether [29,30]. These solvents were used for the extraction because of their different polarity and their ability to dissolve many phytochemical compounds like tannins, polyphenols, flavones, terpenoids and alkaloids [31]. The solvents- powder mixtures were kept at room temperature for $48 \mathrm{hr}$ with rapid stirring every $8 \mathrm{hr}$. The extracts were then filtered through Whatmann No.1 filter papers to exclude undissolved cellular particles. Filtrates were concentrated down to a known volume by evaporation using water bath at $40^{\circ} \mathrm{C}$.Crude plant extracts were then transferred to screw cap bottles and stored at $4^{\circ} \mathrm{C}$ until use [32]. In method B, fifty grams of the powdered plant tissues were suspended in enough distilled water to form a homogeneous suspension. The mixture was adjusted to $\mathrm{pH} 2.0$ with $\mathrm{HCl}(1 \mathrm{~N})$ and then incubated at $37^{\circ} \mathrm{C}$ for $30 \mathrm{~min}$ in a shaking water-bath. The mixture was then neutralized with $\mathrm{NaOH}(1 \mathrm{~N})$ to $\mathrm{pH} 7.0$, filtered, extracted with diethyl ether and concentrated to a known volume by evaporation using water bath at $40^{\circ} \mathrm{C}$. Crude extract obtained for each plant was transferred to screw cap bottles and stored at $4^{\circ} \mathrm{C}$ until use [33]. All solvents were purchased from Merck (Milan, Italy).

\section{Culture media}

Aliquots of $100 \mathrm{ml}$ of nutrient broth were inoculated with individual tested organisms and then incubated at $37^{\circ} \mathrm{C}$ for overnight. Using a sterile pipette, $200 \mu \mathrm{l}$ of the broth culture of each test organism was added to $20 \mathrm{ml}$ of molten agar, which were then cooled at $45^{\circ} \mathrm{C}$, mixed well and poured into a sterile Petri plate. Agar test plates of each test organism were prepared according to [34,35].

\section{Antibacterial bioassay}

To test the antibacterial activity of plant extracts, concentrations of $1024 \mathrm{mg} / \mathrm{l}$ of each extract were used. This was done by dissolving 0.1024 $\mathrm{g}$ of the extracts in $100 \mathrm{ml}$ of $2.5 \%$ Dimethyl sulfoxide (DMSO). This concentration of DMSO was used because it doesn't affect bacterial growth [36]. Wells of five $\mathrm{mm}$ diameters were prepared in the solidified medium and filled with $100 \mu \mathrm{l}$ of different plant extracts. Ciprofloxacin at $20 \mu \mathrm{g} /$ disc was used as positive control [37]. Whereas 2.5\% DMSO

\begin{tabular}{|l|c|c|c|}
\hline \multicolumn{1}{|c|}{ Scientific name } & Taxonomic family & Local name & Part of plant \\
\hline Cadaba glandulosa & Capparidaceae & Qurmot & Leaves \\
\hline Cadaba rotundifolia & Capparidaceae & Qadab & Leaves \\
\hline Euphorbiaina equilatera & Euphorbiaceae & Abo alaban & Makkah-Al-Qunfudahroad \\
\hline Jatrophapel argoniifolia & Euphorbiaceae & Obob & Leaves and stems \\
\hline
\end{tabular}

Table 1: Plant species used in the current study. 
was used as a negative control. The inoculated plates were incubated at $37^{\circ} \mathrm{C}$ for $24 \mathrm{~h}$ and the diameters of inhibition zones were measured.

\section{Determination of minimum inhibitory concentration (MIC)}

The minimum inhibitory concentration (MIC) is defined as the lowest concentration which inhibits any visible bacterial growth [38]. To measure the MIC values of the tested extracts, serial dilutions from the stock extracts $(1024 \mathrm{mg} / \mathrm{l})$ were made to give extracts of 512,256 , $128,64,32,16,8,4 \mathrm{mg} / \mathrm{l}[39]$. The antibacterial activities of these diluted extracts were assayed against the tested bacteria using agar diffusion method as described earlier.

\section{Results}

\section{The antibacterial activity}

I wrote this part when the data was presented as heat maps. In the current version, I data is presented as regular tables. So please remove the highlighted part otherwise present data as it was in heat map format.

\section{Antibacterial activity of Cadaba glandulosa}

Table 2 shows the antibacterial activities of plant extracts prepared from Cadaba glandulosa. In general, the negative control (2.5\% DMSO) showed no inhibition effect on the growth of the tested organisms. On the other hand, the positive control (antibiotic Ciprofloxacin) induced inhibition zones of bacterial growth with different diameters that varied over a range from $20 \mathrm{~mm}$ to $30 \mathrm{~mm}$. These results indicate differential effects of the antibiotic Ciprofloxacin against all tested bacterial strains which justify its choice as a positive control in the current investigation. In addition, the Ciprofloxacin exhibited its maximum inhibitory effect against the growth of K. pneumonia, E. coli, and B. megaterum, whereas the least Ciprofloxacin-induced inhibitory effect was recorded against S. aureus. Our results also indicated that C. glandulosa extract exhibited inhibitory effects on the growth of all tested bacterial strains except $S$. enteretidis. The diameters of the inhibition zones varied over a range from $8 \mathrm{~mm}$ to $19 \mathrm{~mm}$ which translates to a reduction in bacterial growth from $34 \%$ to $68 \%$ among the tested organisms compared to the Ciprofloxacin antibiotic induced bacterial growth inhibition. Regardless the organic solvent and the method of extraction, the C. glandulosa extracts showed their maximum inhibitory effects against the growth of $B$. megaterum, $K$. pneumonia and $P$ aeruginosa. The diameters of the plant extract-induced inhibition zones against these organisms ranged from $16 \mathrm{~mm}$ to $19 \mathrm{~mm}$. On the other hand, the least C. glandulosa extracts-induced bacterial growth inhibition was recorded against $S$. aureus, $B$. cereus and $E$. coli where the inhibition zone diameters varied from $8 \mathrm{~mm}$ to $13 \mathrm{~mm}$.

The antibacterial activity of extracts prepared from C. rotundifolia is presented in (Table 3 ). Our results revealed antibacterial activity similar to that of C. glandulosa, extracts of C. rotundifolia inhibited the growth of all tested bacterial strains except that of $S$. enteretidis. The diameter of the bacterial growth inhibition zones varied from 7 to $19 \mathrm{~mm}$. The highest inhibitory effects were generally obtained against $B$. cereus, $E$. coli and $P$. aeruginosa regardless the kind of organic solvent. Compared to the rest of organic solvents, petroleum ether extract exhibited the highest inhibitory effect on the growth of all tested bacteria. The highest value of the inhibition zones diameter exhibited by petroleum ether extract was against $B$. cereus and $P$. aeruginosa. Interestingly, the petroleum ether extract recovered $76 \%$ and $77 \%$ of the Ciprofloxacininduced bacterial growth inhibition against these 2 organisms respectively. On the other hand, the lowest recovery percentage of the Ciprofloxacin antibacterial activity (33\%) was recorded by the aqueous extract against $K$. pneumoniae. The rest of the tested extracts exhibited intermediate recovery percentages against bacterial strains.

\section{Antibacterial activity of Euphorbia inaequilater}

The antibacterial activity of both E. inaequilater and J. Pleargoniifolia (members of the Euphorbiaceae family) against the same set of bacterial strains were tested and evaluated. Table 4 shows the antibacterial activity of $E$. inaequilater extracts prepared by both extraction method $A$ and $B$ against the tested bacterial strains. Our results indicated that E. inaequilater extracts exhibited inhibitory effect on the growth of all tested bacterial strains including $S$. enteretidis regardless the organic solvent and the method of extraction. Different plant extracts induced significant difference in the diameters of the bacterial growth inhibition zones among bacterial strains. The diameters of the plant extractinduced inhibition zones ranged from $3 \mathrm{~mm}$ to $16 \mathrm{~mm}$. interestingly, the acetone extract tended to have the highest inhibition effect against the growth of the tested bacterial strains compared to the rest of organic solvents. The acetone extract-induced inhibition zones were generally

\begin{tabular}{|c|c|c|c|c|c|c|}
\hline Organism & M & E & $\mathbf{W}$ & A & PE & $\mathrm{DE}$ \\
\hline S. aureus & 0.0 & 0.0 & 10.0 & 0.0 & 0.0 & 11.0 \\
\hline B. megaterum & 0.0 & 0.0 & 12.0 & 7.0 & 12.0 & 15.0 \\
\hline B. cereus & 10.0 & 16.0 & 17.0 & 16.0 & 20.0 & 14.0 \\
\hline E. coli & 16.0 & 15.0 & 12.0 & 16.0 & 15.0 & 12.0 \\
\hline S. enteretidis & 0.0 & 0.0 & 0.0 & 0.0 & 0.0 & 0.0 \\
\hline K. pneumonia & 12.0 & 11.0 & 10.0 & 14.0 & 16.0 & 12.0 \\
\hline P. aeruginosa & 14.0 & 14.0 & 14.0 & 14.0 & 19.0 & 14.0 \\
\hline
\end{tabular}

Table 2: Inhibition zone $(\mathrm{mm})$ of Cadaba glandulosa extracts prepared in different organic solvents by two methods of extractions against selected bacterial strains. Organic solvents are: M: Methanol; E: Ethanol; W: Water; A: Acetone; PE: Petroleum Ether; DE: Diethyl Ether.

\begin{tabular}{|c|c|c|c|c|c|c|}
\hline Organism & M & $E$ & $\mathbf{w}$ & A & PE & DE \\
\hline S. aureus & 0.0 & 8.0 & 8.0 & 13.0 & 12.0 & 11.0 \\
\hline B. megaterum & 19.0 & 16.0 & 18.0 & 19.0 & 17.0 & 18.0 \\
\hline B.cereus & 0.0 & 0.0 & 10.0 & 0.0 & 0.0 & 12.0 \\
\hline E. coli & 10.0 & 0.0 & 11.0 & 10.0 & 00.0 & 10.0 \\
\hline S. enteretidis & 0.0 & 0.0 & 0.0 & 0.0 & 0.0 & 0.0 \\
\hline K. pneumonia & 16.0 & 17.0 & 16.0 & 15.0 & 16.0 & 15.0 \\
\hline P. aeruginosa & 14.0 & 18.0 & 16.0 & 0.0 & 15.0 & 16.0 \\
\hline
\end{tabular}

Table 3: Inhibition zone $(\mathrm{mm})$ of Cadaba rotunifolia extracts prepared in different organic solvents by two methods of extractions against selected bacterial strains. Organic solvents are: M: Methanol; E: Ethanol; W: Water; A: Acetone; PE: Petroleum Ether; DE: Diethyl Ether. 


\begin{tabular}{|c|c|c|c|c|c|c|}
\hline Organism & M & $E$ & $\mathbf{w}$ & A & PE & DE \\
\hline S. aureus & 12.0 & 12.0 & 5.0 & 15.0 & 3.0 & 4.0 \\
\hline B. megaterum & 12.0 & 12.0 & 10.0 & 11.0 & 11.0 & 14.0 \\
\hline B. cereus & 12.0 & 12.0 & 4.0 & 16.0 & 3.0 & 4.0 \\
\hline E. coli & 12.0 & 12.0 & 3.0 & 16.0 & 3.0 & 3.0 \\
\hline S. enteretidis & 13.0 & 12.0 & 4.0 & 16.0 & 4.0 & 3.0 \\
\hline K. pneumonia & 12.0 & 12.0 & 3.0 & 16.0 & 4.0 & 5.0 \\
\hline$P$. aeruginosa & 16.0 & 16.0 & 3.0 & 16.0 & 10.0 & 10.0 \\
\hline
\end{tabular}

Table 4: Inhibition zone $(\mathrm{mm})$ of Euphorbia inaequilatera extracts prepared in different organic solvents by two methods of extractions against selected bacterial strains. Organic solvents are: M: Methanol; E: Ethanol; W: Water; A: Acetone; PE: Petroleum Ether; DE: Diethyl Ether.

around $16 \mathrm{~mm}$. In addition, it is important to point out that extracts prepared by the extraction method B seemed to have inhibitory effects against bacterial strains similar to that induced by the aqueous and petroleum ether extracts prepared by method A. The three extracts exhibited significantly lower inhibition effects on the growth of the tested bacteria than the rest of organic solvents prepared by method A. Compared to the synthetic antibiotic Ciprofloxacin, our results revealed that some $E$. inaequilater extracts can recover a large portion of the Ciprofloxacin antibacterial activity against certain bacterial strains. For example, the alcoholic extracts (methanolic and ethanolic) can recover about $60 \%$ of its antibacterial activity against both $S$. aureus and P. aeruginosa. Whereas the acetone extract can recover about 53\%-75\% of Ciprofloxacin antibacterial activity against all tested organisms.

\section{Antibacterial activity of Jatropha pleargoniifolia}

The antibacterial activity of plant extracts prepared from $J$. Pleargoniifolia against the tested bacterial strains indicated that extracts prepared according to method A did not induce any visible inhibition against any of the tested bacterial strains. On the other hand, extracts prepared by method B showed inhibition zones of growth of all bacterial strains except $S$. enteretidis. The diameters of the extract-induced inhibition zones fluctuated over a range of $12 \mathrm{~mm}$ to $14 \mathrm{~mm}$. The highest inhibitory effect of this extract was recorded against $S$. aureus where the diethyl ether extract recovered $70 \%$ of the Ciprofloxacin antibacterial activity against this bacterial strain. The lowest antibacterial activity of the diethyl ether extract was recorded against $E$. coli where the extract recovered only $41 \%$ of the antibacterial activity of Ciprofloxacin against the same organism. On the other hand, the diethyl ether extracts attained antibacterial activity of about $46 \%$ of that of Ciprofloxacin against the rest of bacterial strains (Table 5).

\section{Minimum inhibitory concentration (MIC)}

The promising and differential antibacterial activities of the tested plant extracts encouraged us to determine the minimum inhibitory concentration of each extract. Therefore, serial dilutions were made from stock extracts $(1024 \mathrm{mg} / \mathrm{l})$ prepared from each plant using methods A and B. The antibacterial activities of the diluted extracts were each tested against the same set of bacterial strains.

\section{Minimum inhibitory concentration (MIC) of Cadaba glandulosa}

The MIC data of plant extracts prepared from C. glandulosa against the tested bacterial strains are shown in (Table 6). Our results revealed that these extracts exhibited MIC values from 16 to $1024 \mathrm{mg}$ plant tissue/l. The MIC values differed significantly among different organic solvents and tested organisms. The lowest MIC values $(16 \mathrm{mg} / \mathrm{l}$ or $32 \mathrm{mg} / \mathrm{l}$ ) were obtained against $B$. megaterum regardless the organic solvents and method of extraction been used. On the other hand, the highest MIC value $(1024 \mathrm{mg} / \mathrm{l})$ was obtained by the aqueous extract against B. cereus. Interestingly, all C. glandulosa extracts showed MIC value of $64 \mathrm{mg} / \mathrm{l}$ against $K$. pneumonia except the petroleum ether extract which exhibited MIC value of $128 \mathrm{mg} / \mathrm{l}$. Similarly, the active $C$. glandulosa extracts attained MIC value of $512 \mathrm{mg} / \mathrm{l}$ against both $E$. coli and $S$. aureus except the acetone extract against $S$. aureus which had a MIC value of $256 \mathrm{mg} / \mathrm{l}$.

Table 7 shows the MIC values of plant extracts prepared from $C$. rotundifolia against the tested bacterial strains. Our results revealed significant differences in MIC values among plant extracts and tested bacterial strains with MIC values changing over a range from 32 $\mathrm{mg} / \mathrm{l}$ to $512 \mathrm{mg} / \mathrm{l}$. The lowest MIC values $(32 \mathrm{mg} / \mathrm{l}$ ) were obtained by petroleum ether plant extract against $B$. cereus and $P$. aeruginosa using extraction method A. In addition, these two bacterial strains tended to be more responsive to the ethanolic, methanolic and the diethyl ether plant extracts than the rest of organic solvents with MIC value of 128 $\mathrm{mg} / \mathrm{l}$. The highest MIC values $(512 \mathrm{mg} / \mathrm{l})$ were obtained by the aqueous extracts against $S$. aureus, and $K$. pneumonia, methanol extract against B. cereus, ethanol extract against $K$. pneumonia, acetone extract against B. megaterum, and diethyl ether extract against $S$. aureus. The rest of plant extracts-bacterial strains interactions showed MIC value of $256 \mathrm{mg} / \mathrm{l}$.

\section{Minimum inhibitory concentration (MIC) of Euphorbia inaequilatera}

The MIC data of plant extracts prepared from E. inaequilatera against the tested bacterial strains are presented in (Table 8). Our results indicated significant differences in MIC values among plant extracts and tested bacterial strains. The MIC values varied over a range from $64 \mathrm{mg} / \mathrm{l}$ to $1024 \mathrm{mg} / \mathrm{l}$. The lowest MIC value $(64 \mathrm{mg} / \mathrm{l})$ was obtained by the acetone plant extract against $B$. megaterum. Interestingly, this plant extract also showed small MIC values $(128 \mathrm{mg} / \mathrm{l})$ against the rest of the tested bacterial strains. Similar MIC values $(128 \mathrm{mg} / \mathrm{l})$ were obtained by both the methanolic and ethanolic extracts against $E$. coli. In addition, these alcoholic extracts also showed relatively small MIC value $(256 \mathrm{mg} / \mathrm{l})$ against the rest of the tested bacterial strains. The aqueous, petroleum ether, and diethyl ether plant extracts showed the highest MIC values $(1024 \mathrm{mg} / \mathrm{l})$ against almost all tested organisms except for $B$. megaterum and $P$ aeruginosa where each of which attained MIC value of $512 \mathrm{mg} / \mathrm{l}$. Among the plant extracts prepared by method $\mathrm{A}$, the aqueous and the petroleum ether extracts were the closest to the diethyl ether extracts (method B) in their MIC values.

\section{Minimum inhibitory concentration (MIC) of Jatropha pelargoniifolia}

The MIC data of plant extracts prepared from J. pelargoniifolia against the tested bacterial strains are presented in (Table 9). Our results indicated that only plant extracts prepared in diethylether according to method B showed MIC values against most of the tested organism. Interestingly, the active diethylether extracts maintained consistent 


\begin{tabular}{|l|c|c|c|c|c|c|}
\hline Organism & M & E & W & A & PE & DE \\
\hline S. aureus & 0.0 & 0.0 & 0.0 & 0.0 & 0.0 & 70.0 \\
\hline B. megaterum & 0.0 & 0.0 & 0.0 & 0.0 & 0.0 & 46.0 \\
\hline B.cereus & 0.0 & 0.0 & 0.0 & 0.0 & 0.0 & 46.0 \\
\hline E. coli & 0.0 & 0.0 & 0.0 & 0.0 & 0.0 & 41.0 \\
\hline S. enteretidis & 0.0 & 0.0 & 0.0 & 0.0 & 0.0 & 0.0 \\
\hline K. pneumonia & 0.0 & 0.0 & 0.0 & 0.0 & 0.0 & 0.0 \\
\hline P. aeruginosa & 0.0 & 0.0 & 0.0 & 0.0 & 0.0 & 12.0 \\
\hline
\end{tabular}

Table 5: Percentages of inhibition zones $(\mathrm{mm})$ of the tested plants extracts compared to the Ciprofloxacin antibacterial activity. Organic solvents are: M: Methanol; E: Ethanol; W: Water; A: Acetone; PE: Petroleum Ether; DE: Diethyl Ether. Wheats, A: Cadaba glandulosa, B: Cadaba rotundifolia, C: Euphorbia inaequilater, D: Jatropha pelargoniifolia.

\begin{tabular}{|c|c|c|c|c|c|c|}
\hline \multirow[t]{2}{*}{ Organism } & \multicolumn{5}{|c|}{ Method A } & \multirow[t]{2}{*}{ Method B } \\
\hline & Methanol & Ethanol & Water & Acetone & Petroleum ether & \\
\hline S. aureus & 0.0 & 512 & 512 & 256 & 512 & 512 \\
\hline B. megaterum & $\underline{32}$ & $\underline{32}$ & 16 & 16 & $\underline{32}$ & 16 \\
\hline B. cereus & 0.0 & 0.0 & 1024 & 0.0 & 0.0 & 512 \\
\hline E. coli & 512 & 0.0 & 512 & 512 & 0.0 & 512 \\
\hline S. enteretidis & 0.0 & 0.0 & 0.0 & 0.0 & 0.0 & 0.0 \\
\hline K. pneumonia & 64 & 64 & 64 & 64 & 128 & $\underline{64}$ \\
\hline P. aeruginosa & 256 & 256 & 256 & 0.0 & 256 & 256 \\
\hline
\end{tabular}

Table 6: Minimum Inhibitory Concentration ( $\mathrm{mg} / \mathrm{l})$ of Cadaba glandulosa extracts prepared in different organic solvents by two extraction methods against Gram-Positive and Gram- negative bacterial strains

\begin{tabular}{|c|c|c|c|c|c|c|}
\hline \multirow[t]{2}{*}{ Organism } & \multicolumn{5}{|c|}{ Method A } & \multirow[t]{2}{*}{ Method B } \\
\hline & Methanol & Ethanol & Water & Acetone & Petroleum ether & \\
\hline S. aureus & 0.0 & 0.0 & 512 & 0.0 & 0.0 & 512 \\
\hline B. megaterum & 0.0 & 0.0 & 256 & 512 & 256 & 256 \\
\hline B. cereus & 512 & 128 & 256 & 128 & $\underline{32}$ & 128 \\
\hline E. coli & 128 & 256 & 256 & 256 & 256 & 256 \\
\hline S. enteretidis & 0.0 & 0.0 & 0.0 & 0.0 & 0.0 & 0.0 \\
\hline K. pneumonia & 256 & 512 & 512 & 256 & 256 & 256 \\
\hline$P$. aeruginosa & 256 & 128 & 256 & 128 & $\underline{32}$ & 128 \\
\hline
\end{tabular}

Table 7: Minimum Inhibitory Concentration (mg/l) of Cadaba rotundifolia extracts prepared in different organic solvents by two methods of extractions against Grampositive and Gram -negative bacterial strains.

\begin{tabular}{|l|c|c|c|c|c|c|}
\hline \multicolumn{1}{|c|}{ Organism } & \multicolumn{3}{|c|}{ Method A } & Method B \\
\cline { 2 - 7 } & Methanol & Ethanol & Water & Acetone & Petroleum ether \\
\hline S. aureus & 256 & 256 & 1024 & 128 & 1024 & 1024 \\
\hline B. megaterum & 256 & 256 & 512 & 64 & 1024 & 1024 \\
\hline B. cereus & 256 & 256 & 1024 & 128 & 1024 & 1024 \\
\hline E. coli & 128 & 128 & 1024 & 128 & 1024 & 1024 \\
\hline S. enteretidis & 256 & 256 & 1024 & 128 & 1024 & 1024 \\
\hline K. pneumonia & 256 & 256 & 1024 & 128 & 512 & 512 \\
\hline P. aeruginosa & 256 & 256 & 1024 & & 124 \\
\hline
\end{tabular}

Table 8: Minimum Inhibitory Concentration ( $\mathrm{mg} / \mathrm{l})$ of Euphorbia inaequilater extracts prepared in different organic solvents by two methods of extractions against Grampositive and Gram -negative bacterial strains.

MIC value of $512 \mathrm{mg} / \mathrm{l}$ against S. aureus, B. megaterum, B. cereus, E. coli, and P. aeruginosa.

\section{Discussion}

In the current study, The antibacterial activity as well as the minimum inhibition concentrations of twenty four plant extracts against seven bacterial strains belonging to Gram-Positive (S. aureus, $B$. megaterium, and B. cereus) and Gram-Negative bacteria (K. pneumonia, $P$. aeruginosa, E. coli, and $S$. enteretidis) were investigated. The plant extracts were prepared from four Saudi's medicinal plants belonging two different taxonomic families: Capparidaceae (Cadaba glandulosa and Cadaba rotundifolia) and Euphorbiaceae (Jatropha pelargoniifolia and Euphorbia inaequilatera) [40-42]. Because of different chemical nature of plant phytochemicals, we employed two different extraction methods with aqueous and six different organic solvents of different polarities for preparation of plant extracts. Our results revealed that all plant extracts, except that of J. pleargoniifolia prepared by method A, had antibacterial activity against the tested Gram-Positive and GramNegative bacteria. Interestingly, significant differences in the diameters of the inhibition zones as well as in the MICs values were observed in different experiments among the tested organisms and different organic solvents. Similar results were obtained by [43]. These results suggest that the tested plant extracts have differential inhibitory efficiencies against bacterial growth. In fact, it has been reported that Cadaba species synthesize a wide variety of bioactive secondary metabolites such as flavonoids, alkaloids terpens [44].Similarly, members of the family Euphorbiaceae synthesize a wide range of secondary metabolites such 


\begin{tabular}{|c|c|c|c|c|c|c|}
\hline \multirow[t]{2}{*}{ Organism } & \multicolumn{5}{|c|}{ Method A } & \multirow[t]{2}{*}{ Method B } \\
\hline & Methanol & Ethanol & Water & Acetone & Petroleum ether & \\
\hline S. aureus & 0.0 & 0.0 & 0.0 & 0.0 & 0.0 & 512 \\
\hline B. megaterum & 0.0 & 0.0 & 0.0 & 0.0 & 0.0 & 512 \\
\hline B. cereus & 0.0 & 0.0 & 0.0 & 0.0 & 0.0 & 512 \\
\hline E. coli & 0.0 & 0.0 & 0.0 & 0.0 & 0.0 & 512 \\
\hline S. enteretidis & 0.0 & 0.0 & 0.0 & 0.0 & 0.0 & 0.0 \\
\hline K. pneumonia & 0.0 & 0.0 & 0.0 & 0.0 & 0.0 & 0.0 \\
\hline$P$. aeruginosa & 0.0 & 0.0 & 0.0 & 0.0 & 0.0 & 512 \\
\hline
\end{tabular}

Table 9: Minimum Inhibitory Concentration (mg/l) of Jatropha pleargoniifolia extracts prepared in different organic solvents by two methods of extractions against Grampositive and Gram -negative bacterial strains.

asphenols, flavonoids, tannins, alkaloids and triterpens, saponinsand essential oils [45]. These bioactive secondary metabolites can effectively interact with critical structural and functional microbial cellular components and thus induce disruption of biological membranes, proton motive force, interruption of electron flow, and coagulation of cellular components. Such interactions usually inhibit or completely stop the microbial growth depending on the quality and quantity of the bioactive compounds in the plant extract as well as the sensitivity of microbial cells to plant phytochemicals. In this regard, it is worth mentioning that the phytochemical content of plants is influenced by many plant and environment-related factors such as the genetic constitution of the plant, developmental stages, plant organs, and mechanisms of plant physiological adaptation to surrounding environmental conditions such as biotic and abiotic stresses. These factors most likely contribute to the possible differences in the phytochemical profiles of the tested plants. Compared to the conventional antibiotic Ciprofloxacin, our results revealed that the tested crude plant extracts prepared from $C$. glandulosa, C. rotundifolia, and E. inaequilaterby method A can recover a significant portion of Ciprofloxacin antibacterial activity against the tested bacterial strains. In addition, significant difference in the recovery efficiency was also observed among the organic solvents. In C. glandulosa, a number of extracts were successfully recovered up to $70 \%$ of Ciprofloxacin's antibacterial activity against the tested bacterial strains. Examples include acetone (65\%) and petroleum ether (60\%) against $S$. aureus, all extracts against $B$. megaterum, ethanolic (72\%) as well as the aqueous extract (64\%) against $P$. aeruginosa. In $C$. rotundifolia, all extracts (62-77\%), except methanol against $B$. cereus and petroleum ether $(76 \%)$ against $P$. aeruginosa. In $E$. inaequilater, methanolic,ethanolic, and acetone extracts recovered about $60 \%$, $64 \%, 75 \%$ of the Ciprofloxacin antibacterial activity against S. aureus, respectively, whereas the recovery efficiency of these extracts were about $64 \%$ against $P$. aeruginosa. On the other hand, in J. pleargoniifolia only plant extracts prepared by method B recovered $70 \%$ against $S$. aureus [46]. Unlike extracts of C. glandulosa and C. rotundifolia which showed selective antibacterial activity at the level of both organic solvent and bacteria strains, the E. Inaequilatera extract exhibited antibacterial activity against all tested organisms regardless the solvent used. Interestingly, the E. Inaequilatera extract showed strong antibacterial activity against $B$. enteretidis which attained consistent resistance against all other tested plant extracts. Among the tested solvents on this plant species, the acetone extract consistently maintained the highest antibacterial activity against all tested organisms. Further, this extract also showed the lowest MIC values (64 or $128 \mathrm{~g} / \mathrm{l}$ ) against all tested organisms. Interestingly, acetone has an intermediate polarity among the tested solvents. It has been reported that solvents with intermediate polarity are more efficient in extraction of bioactive compounds than polar and non-polar solvents [47]. These result suggest a number of important points: (1) the E. Inaequilatera synthesizes a wide diversity of bioactive secondary metabolites of different chemical nature and solubility in aqueous and organic solvent, (2) these compounds are synthesized in amounts high enough to inhibit the growth of bacterial strains, (3) acetone is the most efficient organic solvent in extraction of bioactive compounds in E. Inaequilatera, (4) the low MIC values exhibited by acetone extract as well as by some of the other tested extracts suggest that these extracts either have strong antibacterial potency and/or contain high concentrations of bioactive ingredients, and (5) the E. Inaequilatera synthesis unique bioactive compound(s) that can effectively inhibit the growth of bacteria and that compound(s) can be extracted in any of the tested solvents with acetone.

\section{Conclusion}

The results of the current investigation indicated that most of the tested plant extracts had strong antibacterial activity against the tested Gram-Positive and Gram-Negative bacteria. The antibacterial activities of the tested extract can significantly recover high percentage of that of conventional antibiotics like Ciprofloxacin. The tested extracts also exhibited differential MIC values against the tested bacterial strains. Different organic solvents as well as different extraction methods can be effectively employed to mine plants' phytochemical profiles and consequently illustrate their antibacterial activity against recalcitrant bacterial strains.

\section{References}

1. Latheef SA, Prasad B, Bavaji M, Subramanyam G (2008) A database on endemic plants at Tirumala hills in India. Bioinformation 2: 260-262.

2. Munshi Abdulla, Osman Gamal (2014) Investigation on molecular phylogeny of some date palm (Phoenix dactylifra L.) cultivars by protein, RAPD and ISSR markers in Saudi Arabia. AJCS 1: 23- 28.

3. wolabi OJ, Omogbai EK, Obasuyi O (2007) Antifungal and antibacterial activities of the ethanolic and aqueous extract of Kigelia africana (Bignoniaceae) stem bark. Afr J Biotechnol. 6:1677-1680.

4. Osman G, Munshi A, Altf F, Mutawie H (2013) Genetic variation and relationships of Zea mays and Sorghum species using RAPD-PCR and SDSPAGE of seed proteins. Afr. J. Biotechnol. 12: 4269-4276.

5. Mahesh B, Satish S (2008) Antimicrobial activity of some important medicina plant against plant and human pathogens. WJAS 4: 839-843.

6. Abdel K, Osman G, Amoudi W (2012) Genetic diversity and relationships of some Ipomoea species based on analysis of RAPD-PCR and SDS-PAGE of seed proteins. AJCS 6: 1088-1093.

7. Silva O, Duarte A, Cabrita J, Pimentel M, Diniz A, et al. (1996) Antimicrobia activity of Guinea-Bissau traditional remedies. J Ethnopharmacol 50: 55-59.

8. Kohanski MA, Dwyer DJ, Collins JJ (2010) How antibiotics kill bacteria: from targets to networks. Nat Rev Microbiol 8: 423-435

9. MohamedM, Osman G, Khairou S (2015) Fabrication of Ag nanoparticles modified $\mathrm{TiO}_{2}-\mathrm{CNT}$ heterostructures for enhanced visible light photocatalytic degradation of organic pollutants and bacteria. JECE 3: 1847-1859.

10. Al-Mariri A, Safi M (2014) In Vitro Antibacterial Activity of Several Plant Extracts and Oils against Some Gram-Negative Bacteria. Iran J Med Sci 39: 36-43. 
Citation: Alothyqi N, Almalki M, Albqa'ai M, Alsamiri H, Alrashdi SM, et al. (2016) In Vitro Antibacterial Activity of four Saudi Medicinal Plants. J Microb Biochem Technol 8: 083-089. doi: 10.4172/1948-5948.1000267

11. Ghareeb E, Osman H, Baz AF (2012) Isolation, cloning, and overexpression of vip3Aa gene isolated from a local Bacillus thuringiensis. Biocontrol Sci Techn 22: 11-21.

12. Aibinu I, Aednipekun E, Odugbemi T (2004) Emergence of Quinolone Resistance amongst Escherichia coli strains isolated from Clinical infections in some Lagos State Hospitals, in Nigeria Nigerian. Jpn J Med Sci 3: 73-78.

13. Abdulrahman SA, Osman G (2012) Isolation and Characterization of Gram Negative Obligate and Facultative Alkalophilic Bacillus sp. from Desert Soil of Saudi Arabia. Afr J Biotechnol 11: 9816-9820.

14. Angioni A, Barra A, Coroneo V, Dessi S, Cabras P (2006) Chemical composition, seasonal variability, and antifungal activity of Lavandula stoechas L. ssp. stoechas essential oils from stem/leaves and flowers. J Agric Food Chem 54: 4364-4370.

15. Hussein H, Gamal EH, Abdulrahman SA (2012) Characterization of insecticidal genes of Bacillus thuringiensis strains isolated from arid environments. Indian $\mathrm{J}$ of Microbiol 3: 500-503.

16. Bocanegra V, Corona M, Cabrera M, Rivera G, González E (2009) The bioactivity of plant extracts against representative bacterial pathogens of the lower respiratory tract. BMC Res Notes 2: 95.

17. Chaudhary SA (2001) Flora of the Kingdom of Saudi Arabia: illustrated Riyadh Ministry of Agriculture and Water, National Herbarium, National Agriculture and Water Research Center. Anatomy and morphology 2: 8.

18. Mwine JT (2011) Evaluation of Pesticidal Properties of Euphorbia tirucalli L. (Euphorbiaceae) against Selected Pests. 145

19. Awaad S, Meligy Y, Moustafa A (2014) Method of extracting and isolation flavonoids from Euphorbia cuneata. Afr J Biotechnol 11: 9816-9820.

20. Gohar AA1 (2002) Flavonol glycosides from Cadaba glandulosa. Z Naturforsch C 57: 216-220.

21. Velmurugan P, Kamaraj M, Prema D (2011) Phytochemical constituents of Cadaba trifoliata Roxb. root extract. Int J Pharm 2: 11.

22. Dastagir G, Hussain F, Khan AA (2012) Antibacterial activity of some selected plants of family Zygophyllaceae and Euphorbiaceae. J of Medi Plants Res. 6: 5360-5368.

23. Hassan S, Umar R, Lawal M, Bilbis L, Muhammad B (2006) Evaluation of antibacterial activity and phytochemical analysis of root extracts of Boscia angustifolia. Afr J Biotechnol 5: 1602-1607.

24. Brusotti G, Cesari I, Dentamaro A, Caccialanza G, Massolini G (2014) Isolation and characterization of bioactive compounds from plant resources: the role of analysis in the ethnopharmacological approach. J Pharm Biomed Anal 87: 218-228.

25. Chaudhary SA (2001) Flora of the Kingdom of Saudi Arabia. Afr J Biotechno 2: 153-159.

26. Akinsulire OR, Aibinu IE, Adenipekun T, Adelowotan T, Odugbemi T (2007) Invitro antimicrobial activity of crude extracts from plants Bryophyllum pinnatum and Kalanchoe crenata. Afr J Tradit Complement Altern Med 4: 338-344.

27. Osman G, Assaeedi A, Osman Y, El-Ghareeb D, Alreedy R (2013) Purification and characterization of Bacillus thuringiensis vegetative insecticidal toxin protein(s). Lett Appl Microbiol 57: 310-316.

28. Osman G, Already R, Assaeedi A, Organji S, El-Ghareeb D, et al. (2015) Bioinsecticide Bacillus thuringiensis a comprehensive Review. Egypt J Biol Pest Co Journal 25: 271-288.

29. Prakash M, Kumar S, Karmegam N (2006) Synergistic effect of selected medicinal plant extracts against certain bacteria Indian. J Appl Microbiol 6: 52-53.

30. Karuppusamy S, Karmegam N, Rajasekaran K (2011) Antimicrobial screening of Asclepiadacean medicinal plants of Dindigul district Tamil Nadu, South India. Jof Ecotoxicol and Environ Monit 11: 47-52.

31. Bakht J, Muhammad T, Ali H, Islam A, Shafi M (2013) Effect of different solvent extracted sample of Allium sativum (Linn) on bacteria and fungi African. J of Biotechnol 10: 5910-5915.
32. Prakash $M$, Karmegam N (2012) Invitro antibacterial activity of certain plant extracts against plant disease causing bacteria isolated from citrus plant. Int $J$ Curr Microbiol App Sci 1: 1-11.

33. Sarraj S, Redha F, Mahmoud M, Hussein W (1985) Modified extraction procedure for the active constituents of some Iraqi medicinal plants. Fitoterapia 2: 19-25.

34. Irshad S, Mahmood M, Perveen F (2012) In vitro antibacterial activities of three medicinal plants using agar well diffusion method Research. J Biol 2: 1-8.

35. Osman G, Mostafa S, Sonya H (2007) Antagonistic Activities of some streomycete isolates against some phytopathogenes. Pak J Biotecnol 7: 65-71.

36. Djeussi E, Noumedem K (2013) Antibacterial activities of selected edible plants extracts against multidrug-resistant Gram-negative bacteria. BMC Complement Altern Med 13: 164.

37. Momani F, Alkofahi AS, Mhaidat NM (2011) Altholactone displays promising antimicrobial activity. Molecules 16: 4560-4566.

38. Bonjar GS (2004) Evaluation of antibacterial properties of Iranian medicinalplants against Micrococcus luteus, Serratia marcescens, Klebsiella pneumoniae and Bordetella bronchoseptica. Asian J Plant Sci 3:82-86.

39. Sader HS, Flamm RK, Jones RN (2013) Antimicrobial activity of daptomycin tested against Gram-positive pathogens collected in Europe, Latin America, and selected countries in the Asia-Pacific Region (2011). Diagn Microbiol Infect Dis 75: 417-422.

40. Panghal M, Kaushal V, Yadav JP (2011) In vitro antimicrobial activity of ten medicinal plants against clinical isolates of oral cancer cases. Ann Clin Microbiol Antimicrob 10: 21.

41. Heba H, Osman G, Ramadan A (2015) Development of transgenic wheat (Triticum aestivum L.) expressing avidin gene conferring resistance to stored product insects. BMC Plant Biol 15: 183-190.

42. Perumal Samy R, Gopalakrishnakone P (2010) Therapeutic Potential of Plants as Anti-microbials for Drug Discovery. Evid Based Complement Alternat Med 7: 283-294.

43. Nostro A, Germanò MP, D'angelo V, Marino A, Cannatelli MA (2000) Extraction methods and bioautography for evaluation of medicinal plant antimicrobial activity. Lett Appl Microbiol 30: 379-384.

44. Awanchiri SS, Trinh-Van-Dufat $H$, Shirri JC, Dongfack MD, Nguenang GM, et al. (2009) Triterpenoids with antimicrobial activity from Drypetes inaequalis. Phytochemistry 70: 419-423.

45. Gressler V, Stüker CZ, Dias Gde O, Dalcol II, Burrow RA, et al. (2008) Quinolone alkaloids from Waltheria douradinha. Phytochemistry 69: 994-999.

46. Angioni A, Barra A, Coroneo V, Dessi S, Cabras P (2006) Chemica composition, seasonal variability, and antifungal activity of Lavandula stoechas L. ssp. stoechas essential oils from stem/leaves and flowers. J Agric Food Chem 54: 4364-4370.

47. Eloff JN, Famakin JO, Katerere DRP (2005) Combretum woodii (Combretaceae) leaf extracts has high activity against Gram-negative and Gram-positive bacteria. Afr J Biotechnol 4: 1161-1166. 